\title{
PENGEMBANGAN HANDOUT BERMUATAN PENDIDIKAN KARAKTER BERBASIS KONTEKSTUAL PADA MATERI KINGDOM PLANTAE DI KELAS X SMAK FRATER DON BOSCO TARAKAN
}

\section{Development of Handouts with Contextual-Based Character Education on Kingdom Plantae Material for Tenth Grade Students of SMAK Frater Don Bosco Tarakan}

\author{
Susi Yantika Siahaan ${ }^{\mathrm{a}^{*}}$,Fitri Wijarini ${ }^{\mathrm{b}}$, Aidil Adhanic ${ }^{\mathrm{c}}$
}

a Mahasiswa Program Studi Pendidikan Biologi, Universitas Borneo Tarakan, Tarakan, Kalimantan Utara, Indonesia $b$ Studi Pendidikan Biologi, Universitas Borneo Tarakan, Tarakan, Kalimantan Utara, Indonesia Corresponding author: Jl. Amal Lama, Tarakan Timur, Tarakan, Kalimantan Utara, 77123, Indonesia. E-mail: susiyantikasiahaan@gmail.com

\begin{abstract}
Abstrak
Penelitian ini bertujuan untuk menghasilkan Handout Bermuatan Pendidikan Karakter Berbasis Kontekstual Pada Materi Kingdom Plantae di Kelas X SMAK Frater Don Bosco Tarakan yang berkualitas dari segi kelayakan dan respon siswa. Penelitian ini merupakan jenis penelitian Research and Development $(R \& D)$ dengan menggunakan model pengemmbangan 4D yang terdiri dari 4 tahap yaitu Define, Design, Development, Disseminate. Akan tetapi, pada pengembangan ini hanya dilakukan sampai tahap ke 3 yaitu tahap Development. Data penelitian dianalisis melalui uji kelayakan dan respon siswa. Pengujian produk dilakukan oleh validator ahli media, ahli materi, dan praktisi (guru biologi). Uji coba lapangan dilakukan secara online melalui google formulir yang dibagikan pada siswa SMAK Frater Don Bosco Tarakan kelas XI IPA dengan jumlah siswa sebanyak 30 orang. Hasil validasi yang diperoleh dari ahli media sebesar 89\% dengan kategori sangat layak, ahli materi sebesar 96\% dengan kategori sangat layak, praktisi sebesar 94\% dengan kategori sangat layak dan respon siswa sebesar 87\% dengan kategori sangat menarik. Berdasarkan hasil penelitian tersebut, maka dapat disimpulkan bahwa Handout Bermuatan Pendidikan Karakter Berbasis Kontekstual Pada Materi Kingdom Plantae yang dikembangkan telah memenuhi kriteria kualitas bahan ajar yang baik dan layak digunakan dalam pembelajaran biologi di sekolah.
\end{abstract}

Kata Kunci: Bahan Ajar, Handout, Pendidikan karakter, Kontekstual.

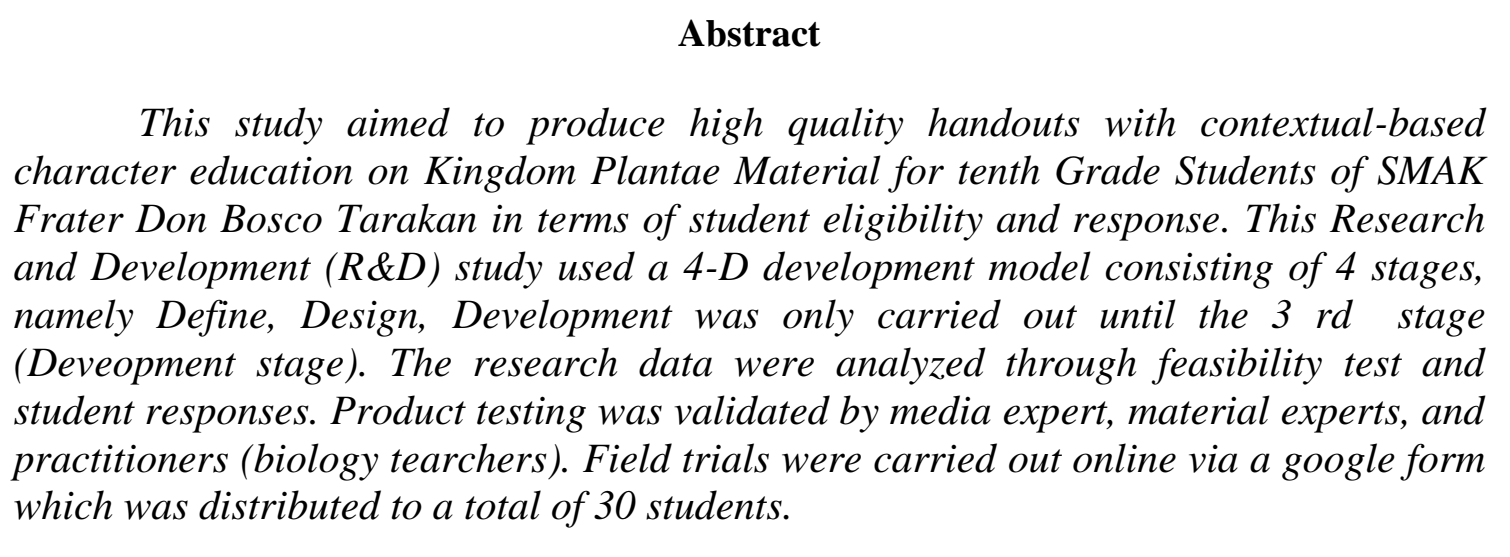




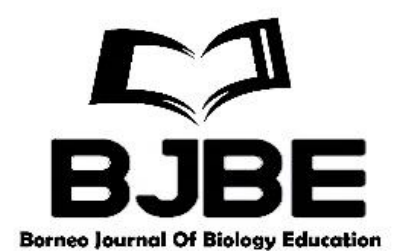

Vol. 3 No. 1, 2021; pp. 29-41

P-ISSN: 2715-6826 (print); E-ISSN: 2714-6073 (online)

Received: 16/02/2021

Revised: 03/03/2021

Accepted: 18/03/2021

The validations result obtained from media experts were $89 \%$ which meant very feasible, 96\% from material experts meaning feasible, $94 \%$ from practitioners meaning very feasible, $87 \%$ from student response meaning very interesting. It could be concluded that the handout with Contextual-Based Character Education on the Kingdom Plantae material developed met the criteria for good quality teaching materials and was suittable for use in learning biology in the school.

Keywords: Teaching Materials, Handouts, Character education, Contextual.

\section{Pendahuluan}

Pendidikan merupakan suatu usaha masyarakat dan bangsa dalam mempersiapkan generasi muda yang memiliki kemampuan, kepribadian, dan keterampilan sesuai dengan tuntutan perkembangan zaman (Anggela, Masril, Yenni Darvina 2013). Adapun fungsi pendidikan nasional diterapkan dalam kurikulum 2013 yang berlangsung saat ini. Kurikulum mempunyai kedudukan sentral dalam seluruh proses pendidikan serta mengarahkan segala bentuk aktivitas pendidikan demi tercapainya tujuan pendidikan yang tercantum dalam Undang-Undang No. 20 Tahun 2003. Menurut Mendikbud Mohammad Nuh (Mulyoto,2013) implementasi kurikulum 2013 akan menekankan pada pengembangan kreativitas siswa dan penguatan karakter. Tiga komponen utama dalam kurikulum pendidikan, meliputi pengetahuan, keterampilan, dan sikap. Landasan konseptual dari kurikulum 2013 adalah berbasis kompetensi dan karakter (Mumtazah, 2015). Salah satu komponen kurikulum 2013 yang ditekankan adalah pendidikan karakter.

Pendidikan karakter adalah suatu usaha yang disengaja untuk membantu seseorang sehingga ia dapat memahami, memperhatikan, dan melakukan nilai-nilai etika yang tinggi (Lickona, 2006). Internalisasi pendidikan karakter dapat dituangkan dalam sebuah bahan ajar dengan merevisi atau menambahkan nilai-nilai karakter, seperti nilai kereligiusan, kepedulian, kejujuran, kemandirian dan nilai pedidikan karakter lain dalam pembahasan materi yang ada di dalamnya. Sesuai dengan permasalahan yang ditemukan pada beberapa siswa di SMAK Frater Don Bosco Tarakan. Berdasarkan pernyataan dari guru BP dan guru mata pelajaran, ada beberapa siswa dalam setiap kelas yang mempunyai sifat atau karakter yang kurang baik yang tidak dikenankan sebagai seorang siswa pelajar.

Penyajian bahan ajar dengan bermuatan pendidikan karakter diharapkan dapat membentuk kepribadian peserta didik yang memiliki karakter mulia sesuai dengan normanorma agama, hukum, tata krama, budaya, dan adat istiadat yang tertanam dalam bahan ajar. Guru dapat menambahkan atau mengadapsi kegiatan pembelajaran sekaligus pengembangan karakter siswa dalam sebuah bahan ajar (Asriani, 2017). Bahan ajar merupakan komponen yang sangat penting dalam proses belajar mengajar. Hal ini sesuai dengan pernyataan Meilan, (2018) dan Elmi (2017) berpendapat salah satu komponen yang penting untuk mengoptimalkan sistem pembelajaran adalah keberadaaan dan penggunaan bahan ajar bagi siswa. Salah satu bahan ajar yang dapat dikembangkan adalah bahan ajar berupa handout. Handout merupakan bahan ajar tertulis dan sangat ringkas yang bersumber dari 


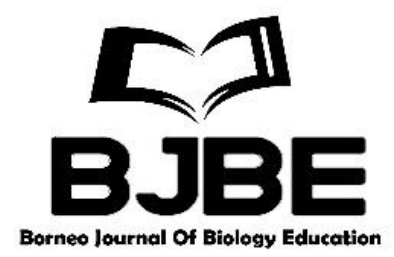

Vol. 3 No. 1, 2021; pp. 29-41

P-ISSN: 2715-6826 (print); E-ISSN: 2714-6073 (online)

Received: $16 / 02 / 2021$

Revised: 03/03/2021

Accepted: 18/03/2021

beberapa literatur yang relevan terhadap kompetensi dasar dan materi pokok yang diajarkan kepada peserta didik (Prastowo, 2012). Pembahasan didalam handout memuat konsep-konsep penting saja, sehingga akan lebih mudah dipahami oleh siswa. Pemberian bahan ajar berupa handout bertujuan untuk memotivasi siswa dalam belajar apalagi jika ditampilkan dengan gambar dan bentuk yang menarik. Sesuai dengan permasalahan yang ditemukan di SMAK Frater Don Bosco melalui wawancara dan pengisian angket oleh siswa didapatkan bahwa Sekitar 89,65\% dari 29 orang siswa menginginkan bahan ajar terbaru. Selain itu mereka juga menginginkan bahan ajar yang dengan penyajian materi yang terangkum dengan baik, singkat, padat dan jelas serta menyediakan gambar-gambar yang menarik terkait materi pembelajaran. Siswa cenderung bosan dan kurang mengerti menggunakan bahan ajar berupa buku paket yang sangat monoton tanpa ditampilkan dengan gambar-gambar yang menarik dan juga keberadaan bahan ajar yang terbatas. Keberadaan bahan ajar tanpa memperhatiikan pendekatan dalam mengembangkan materi dari bahan ajar tersebut tidak akan membawa manfaat yang besar. Salah satu pendekatan belajar yang selama ini dianggap cocok untuk pembelajaran biologi adalah pendekatan kontekstual (Rufa, Khairil, Hasanuddin 2014).

Pembelajaran kontekstual adalah pembelajaran yang mendorong siswa untuk menjembatani antara pengetahuan teoritis yang diperoleh di dalam kelas dengan kehidupan sehari-hari (Komalasari, 2013). Pembelajaran kontekstual sesuai dengan karakteristik materi biologi pada kingdom plantae yang sangat erat kaitannya dengan kehidupan sehari-hari di lingkungan. Berdasarkan hasil pengalaman mengajar selama PPL serta observasi di SMAK Frater Don Bosco Tarakan didapatkan fakta bahwa; 1) Guru mata pelajaran biologi, dan siswa mengatakan bahwa pembelajaran berbasis kontekstual masih kurang optimal diterapkan di sekolah, 2) Melalui wawancara dan pengisian angket didapat bahwa 90\% siswa menginginkan guru mengajar dengan metode melakukan diskusi kelompok dan praktikum pada setiap materi pembelajaran, 3) sekitar $86,6 \%$ siswa menyatakan mata pelajaran biologi menjadi mata pelajaran yang tergolong sulit tetapi juga menyenang bagi mereka, 4) katersediaan bahan ajar belum bervariasi, $93 \%$ siswa mengatakan sumber belajar yang digunakan hanya buku paket saja, 5) salah satu materi yang tergolong sulit dipahami siswa adalah kingdom plantae, hal ini sesuai dengan hasil pengisian angket yang dipersentasikan bahwa $50 \%$ siswa memilih materi yang sulit adalah kingdom plantae, 33,3\% materi Protista, $10 \%$ jamur dan sisanya tidak ada. Materi kingdom plantae pada tingkat SMA merupakan salah satu pokok bahasan pelajaran biologi kelas X semester genap.

Kingdom plantae merupakan salah satu materi yang dianggap sulit dipelajari oleh beberapa siswa, karena pada materi Plantae objek yang dipelajari sangat banyak dan sulit untuk dibedakan antara objek yang satu dengan objek yang lain. Siswa juga kebingungan menyusun konsep dan menentukan berbagai penggolongannya. Kesulitan dalam memahami materi pembelajaran menyebabkan kurangnya motivasi belajar siswa dan pemahamannya akan materi kingdom plantae. Hal ini sejalan dengan penelitian Wahyuni (2015) yang menyatakan bahwa materi kingdom plantae yang tergolong sulit karena banyak cakupan materi yang terdiri dari ciri-ciri, klasifikasi, reproduksi, dan peranannya bagi kehidupan serta sulitnya siswa untuk dapat menggabungkan konsep-konnsep esensial dan menggabungkan suatu konsep dengan konsep lainnya yang berpengaruh pada hasil belajar siswa. 


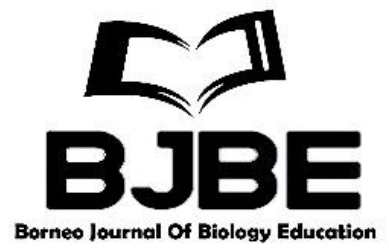

Vol. 3 No. 1, 2021; pp. 29-41

P-ISSN: 2715-6826 (print); E-ISSN: 2714-6073 (online)

Received: 16/02/2021

Revised: 03/03/2021

Accepted: 18/03/2021

Sesuai dengan permasalahan tersebut maka salah satu jenis bahan ajar yang siswa perlukan dan bisa dikembangkan oleh guru adalah Handout. Pengembangan ini didukung dengan fakta gaya belajar siswa kelas $\mathrm{X}$ di SMAK Frater Don Bosco Tarakan didapat persentase bahwa sekitar 23,96\% gaya belajar siswa ke arah visual, 23,21\% auditori, dan sekitar 22,32\% kinestetik. Persentase tersebut didapat dari hasil pengisian angket gaya belajar yang dilakukan oleh siswa di sekolah. Persentase gaya belajar kearah visual siswa sejalan dengan pengisian angket bahan ajar yang diinginkan siswa, sekitar 89,65 \% siswa mengharapkan bahan ajar yang singkat, padat dan jelas, dan penuh dengan gambar yang berwarna. Banyaknya permasalahan yang ditemukan, memotivasi peneliti melakukan pengembangan handout dengan judul"Pengembangan Handout Bermuatan Pendidikan Karakter Berbasis Kontekstual Pada Materi Kingdom Plantae di kelas X SMA Frater Don Bosco Tarakan" yang diharapkan mampu untuk mengatasi segala kekurangan bahan ajar sebelumnya.

\section{Material dan metode}

Penelitian ini adalah penelitian pengembangan atau Research and Deelopment $(R \& D)$. Sugiyono (2014) menyatakan bahwa Research and Development $(R \& D)$ merupakan metode peneitian yang digunakan untuk menghasilkan produk tertentu, dan menguji keefektifan produk tersebut. Penelitian ini akan dilakukan pada beberapa siswa yang menjadi kelas uji coba. Sekolah yang akan digunakan adalah SMAK Frater Don Bosco Tarakan. Siswa yang akan mengisi angket melalui google form adalah siswa yang sudah mempelajari materi Kingdom Plantae sebelumnya yaitu kelas IX IPA. Jenis data yang didapat merupakan data kuantitatif dan data kualitatif.

Teknik analisis yang digunakan dalam penelitian dan pengembangan ini yaitu data dari hasil validasi oleh ahli materi dan ahli media diperoleh dalam bentuk data kualitatif dan kuantitatif. Data kualitatif berupa kritik dan saran akan dijadikan sebagai pedoman dalam perbaikan bahan ajar yang dikembangkan. Sedangkan data kuantitatif yang diperoleh akan dihitung menggunakan penilaian skor standar dari Riduwan (2013). Kriteria penilaian ahli menggunakan skala Likert dengan skala 1-5.

Tabel 1. Kriteria Penskoran

\begin{tabular}{cc}
\hline Kriteria & Nilai/Skor \\
\hline Sangat Kurang & 1 \\
Kurang & 2 \\
Cukup & 3 \\
Baik & 4 \\
Sangat Baik & 5 \\
\hline
\end{tabular}

(Sumber: Ridwan, 2013) 


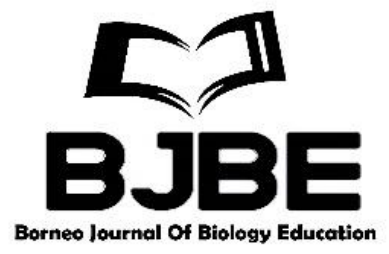

Vol. 3 No. 1, 2021; pp. 29-41

P-ISSN: 2715-6826 (print); E-ISSN: 2714-6073 (online)

Received: 16/02/2021

Revised: 03/03/2021

Accepted: 18/03/2021

Selanjutnya perhitungan menggunakan rumus pada Formula 1.

$$
\mathrm{NP}=\frac{R}{S M} \times 100 \%(\text { Formula } 1)
$$

Keterangan :

NP : Persentase Kelayakan

$\mathrm{R} \quad$ : Skor yang diperoleh

SM : Skor maksimal

Setelah memperoleh persentase kelayakan, kemudian nilai tersebut akan di interpretasikan menurut tabel kriteria penilaian validator pad Tabel 2.

Tabel 2. Persentase Kelayakan Produk

\begin{tabular}{cc}
\hline Persentase & Kriteria \\
\hline $0 \%-20 \%$ & Sangat tidak layak \\
$2 \%-40 \%$ & Kurang layak \\
$41 \%-60 \%$ & Cukup layak \\
$61 \%-80 \%$ & Layak \\
$81 \%-100 \%$ & Sangat layak \\
\hline
\end{tabular}

(Sumber : Riduwan, 2013)

Handout yang dikembangkan dikatakan layak digunakan apabila semua aspek dalam angket ahli/pakar memperoleh persentase sebesar $\geq 61 \%$ dengan kriteria layak maupun sangat layak. Setelah dianalisis, jika hasilnya perlu direvisi maka akan dilakukan revisi dan jika hasilnya layak digunakan maka produk siap untuk di uji cobakan (Riduwan, 2013).

Nilai persentase skor angket siswa dihitung menggunakan perhitungan dari Riduwan (2013). Rumus yang digunakan dijabarkan pada Formula 2. Persentase yang diperoleh kemudian dikategorikan dalam kriteria di Tabel 2.

$$
\text { Persentase }=\frac{\text { jumlah skor hasil pengumpulan data }}{\text { jumlah skor kriterium }} \times 100 \% \quad \text { (Formula 2) }
$$

dimana $:$ skor kriterium $=($ skor tertinggi tiap item $) \times($ jumlah item $) \times($ jumlah responden $)$.

Bahan ajar yang dikembangkan mendapatkan respon yang baik apabila semua aspek dalam angket respon siswa memperoleh persentase sebesar $\geq 61 \%$ dengan kriteria menarik maupun sangat menarik (Riduwan, 2013).

\section{Uji Kelayakan}

\section{Hasil dan Pembahasan}

Handout bermuatan pendidikan karakter berbasis kontekstual sebagai bahan ajar pada materi kingdom plantae untuk kelas X SMAK Frater Don Bosco Tarakan yang dikembangkan ini, telah divalidasi oleh validator ahli media, ahli materi dan praktisi dimana divalidasi langsung oleh dosen program studi pendidikan biologi di Universitas Borneo Tarakan dan praktisi oleh guru biologi di sekolah. Hasil validasi ahli terhadap Handout 


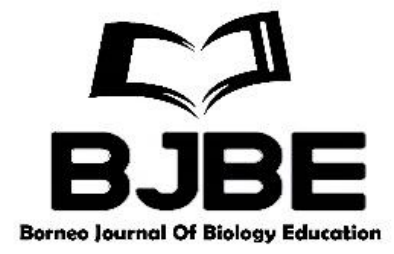

Vol. 3 No. 1, 2021; pp. 29-41

P-ISSN: 2715-6826 (print); E-ISSN: 2714-6073 (online)

Received: $16 / 02 / 2021$

Revised: 03/03/2021

Accepted: 18/03/2021

pembelajaran biologi bermuatan pendidikan karakter berbasis kontekstual pada materi kingdom plantae di kelas X SMAK Frater Don Bosco Tarakan di tujukan untuk mengetahui kualitas Handout dari segi kelayakan Handout yang meliputi aspek desain beberapa aspek yang di nilai.

Tabel 5. Rekapitulasi Persentase Skor Aspek Kelayakan

\begin{tabular}{cccc}
\hline No & Validator & Persentase Skor $(\%)$ & Keterangan \\
\hline 1 & Ahli Media & $89,4 \%$ & Sangat Layak \\
2 & Ahli Materi & $96 \%$ & Sangat Layak \\
3 & Praktisi & $94 \%$ & Sangat layak \\
& Rata-rata & $93 \%$ & Sangat Layak \\
\hline
\end{tabular}

Validasi ahli dilakukan untuk mengetahui kualitas kelayakan Handout yang disajikan, Handout dikatakan layak apabila hasil validasi ahli mencapai rentang persentase penilaian sebesar (61\%-80\%) dengan kategori layak dan 81\%-100\% dengan kategori sangat layak (Riduwan 2014). Berikut ini uraian dari hasil validasi oleh beberapa validator.

Validasi ahli media dilakukan bertujuan untuk mengetahui kelayakan media yang dikembangkan melalui tahap validasi oleh ahli media. Validasi mencakup 5 aspek yang terdiri dari 17 kriteria yang akan dinilai yaitu, aspek desain Handout, tampilan, karakteristik bahan ajar, kriteria fisik, serta penyelesaian dan jilid dengan nilai persentase sebesar 89\% tersebut dikategorikan dalam kategori sangat layak. Validasi yang dilakukan terhadap media memperoleh persentase tertinggi pada aspek keempat, yaitu aspek kriteria fisik, diperoleh nilai persentae sebesar $100 \%$ dengan kategori sangat layak. Beberapa komponen pada aspek kriteria fisik yaitu, penggunaan huruf cetak tebal, miring, dan warna pada Handout. Handout yang dikembangkan telah sesuai, dengan penggunaan huruf cetak tebal pada bagian judul besar dan sub judul, penggunaan kata atau kalimat dengan huruf miring pada bahasa asing atau bahasa ilmiah jenis tumbuhan yang tergolong Kingdom Plantae, serta warna pada Handout yang telah dibuat bervasiasi dengan warna yang seimbang seperti saran dari ahli media sebelumnya yang mengatakan bahwa perpaduan warna harus disesuaikan pada setiap tampilan atau halaman.

Khoirot (2016) menyatakan bahwa penempatan huruf tebal, miring, garis bawah atau warna harus sesuai untuk isi bahan ajar sehingga menimbulkan daya tarik dan kenyamanan bagi pembaca. Selanjutnya pada aspek kriteria fisik terdapat juga kesesuaian bentuk dan ukuran huruf pada Handout bermuatan pendidikan karakter berbasis kontekstual. Kesesuaian bentuk dan ukuran huruf harus menjadi hal yang sangat penting diperhatikan, karena ini akan menjadi salah satu alasan yang membuat kemenarikan Handout. Bentuk dan ukuran huruf harus seimbang dan sesuai dengan penempatan kata atau kalimat dalam bahan ajar. Sesuai dengan pernyataan Purwanto dan Sudjadi (2014) mengatakan bahwa bahan ajar yang baik harus mampu mengajak pembaca untuk merespon, berkonsentrasi, gaya bahasa, warna dan sebagainya, memuat ilustrasi yang sesuai/terkait dengan teks, penempatan ilustrasi tepat, ukuran, kefokusan dan tampilan seimbang dan serasi. Tampilan kriteria fisik yang jelas dan menarik diharapkan dapat memberikan kemudahan bagi pembaca serta menambah daya tarik Handout sehingga menarik minat siswa untuk membacanya.

Selanjutnya, aspek yang memperoleh persentase terendah pada bahan ajar Handout adalah aspek yang ketiga yaitu aspek karakteristik bahan ajar Handout dengan perolehan persentase sebesar 85\% dengan kategori sangat layak. Aspek ini terdiri dari empat komponen dalam aspek karakteristik yaitu, bahan ajar Handout yang dikembangkan bersifat Self 


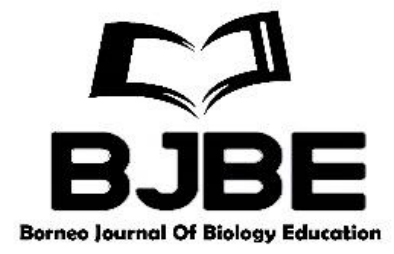

Vol. 3 No. 1, 2021; pp. 29-41

P-ISSN: 2715-6826 (print); E-ISSN: 2714-6073 (online)

Received: $16 / 02 / 2021$

Revised: 03/03/2021

Accepted: 18/03/2021

Instructional (membelajarkan peserta didik, tidak bergantung pada pihak lain) artinya Handout yang dikembangkan dapat digunakan oleh siswa secara mandiri atau dengan bimbingan guru sehingga siswa dapat belajar disekolah ataupun dirumah. Selanjutnya bahan ajar hendaknya bersifat Self Contained (Mencakup keseluruhan materi Kingdom Plantae). bersifat Adaptive (sesuai dengan perkembangan ilmu dan kurikulum yang berlaku). Terakhir, bersifat User Friendly (Bersahabat dengan Pembaca) dalam artian penyampaian dan isi Handout mudah dipahami oleh pembaca. Setiap intruksi dan paparan informasi yang tampil bersifat membantu dan bersahabat dengan pemakainya termasuk kemudahan pemakai dalam mendapatkannya (Arsanti, 2018). Hal ini sesuai dengan penyataan Depdiknas (2008) menyatakan bahwa karakteristik bahan ajar yang baik adalah bahan ajar yang tidak bergantung pada media lain saat digunakan siswa. Berdasarkan komentar dan saran yang diberikan oleh validator, maka pengembang telah melakukan revisi beberapa kali untuk melengkapi berbagai bagian dari Handout sampai benar-benar layak digunakan oleh siswa. Hal ini sesuai dengan pernyataan Masnur (2010) yang menyatakan bahwa prinsip bahan ajar adalah mengkombinasikan gambar, warna, dan materi yang disusun secara menarik untuk menarik minat membaca siswa pada bahan ajar tersebut.

Berdasarkan hasil analisis validasi ahli materi pada tabel, menunjukkan Handout yang dikembangkan memperoleh persentase sebesar 96\% dengan kategori sangat layak. Angket penilaian ahli materi memuat 5 aspek dengan 17 komponen yang dinilai diantaranya aspek cakupan materi, aspek keakuratan materi, pendekatan kontekstual, muatan pendidikan karakter, dan aspek bahasa. Beberapa aspek yang memperoleh penilaian tertinggi dengan persentase $100 \%$ adalah aspek pendekatan kontekstual, muatan pendidikan karakter dan bahasa.

Aspek yang pertama dengan perolehan persentase tertinggi sebesar $100 \%$ adalah aspek cakupan pendekatan kontekstual dengan kategori sangat layak, dengan 2 kriteria yakni, keterkaitan antara materi yang diajarkan dengan pengetahuan yang dimiliki oleh siswa, kemampuan mendorong siswa membuat hubungan antara pengetahuan yang dimiliki siswa dengan penerapannya dalam kehidupan sehari-hari ini dikategorikan baik atau layak. Dikarenakan sebagian besar gambar yang terdapat dalam materi pembelajaran adalah gambar yang diambil dari hasil penelitian di lapangan. Gambar diambil dari lingkungan sekitar siswa dengan tujuan agar siswa mudah mengenal dan memahami isi materi. Komalasari, (2017) menyatakan suatu gambar atau foto dapat memberikan gambaran gambaran nyata yang menunjukkan objek sesungguhnya, memberikan makna pembelajaran yang lebih hidup dan tepat dibandingkan dengan kata-kata sehingga meransang kemampuan berfikir siswa. Dengan demikian sumber belajar akan berpengaruh positif terhadap kegiatan pembelajaran terutama pada peningkatan motivasi belajar siswa. Serta penugasan praktikum sederhana yang juga di tampilkan dalam Handout adalah berbasis kontekstual yakni siswa melalukan penelitian langsung di lingkungannya dengan mengaitkan teori atau pengetahuan yang dimilikinya dengan apa yang ditemukan di lingkungan sekitarnya.

Aspek dengan perolehan penilaian terendah adalah aspek cakupan materi dengan persentase $93 \%$ dalam kategori sangat layak. komponen cakupan materi yang dinilai yakni, kesesuaian materi sebagai pendukung SK, KD, dan Indikator, kesesuaian materi sebagai pendukung tujuan pembelajaran, hal ini menunjukkan bahwa materi Kingdom Plantae yang terdapat dalam Handout yang dikembangkan telah sesuai dengan silabus kurikulum 2013, standar kompetensi, kompetensi dasar, indikator dan tujuan pembelajaran. Hal ini dipertegas oleh Depdiknas (2008) bahwa Handout disusun atas dasar KD yang harus dicapai oleh siswa. Dengan demikian Handout harus diturunkan dari kurikulum. Kriteria selanjutnya penyajian materi, kesesuaian peta konsep dengan materi yang berfungsi untuk membantu siswa 


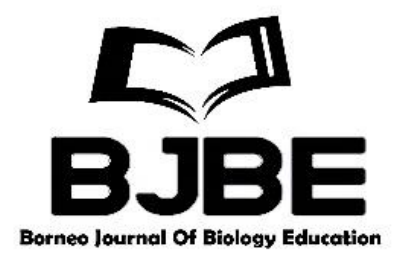

Vol. 3 No. 1, 2021; pp. 29-41

P-ISSN: 2715-6826 (print); E-ISSN: 2714-6073 (online)

Received: $16 / 02 / 2021$

Revised: 03/03/2021

Accepted: 18/03/2021

mengetahui point-point utama yang harus dipelajari dalam Handout dan dapat membantu siswa untuk mengetahui hubungan antara topik pada materi yang satu dengan yang lainnya dalam Handout.

Sesuai dengan pernyataan Prastowo (2012) menyatakan bahwa peta konsep yang terdapat dalam bahan ajar berfungsi memberikan informasi penting tentang hubungan antar topik, sehingga pembaca lebih mudah melihat ruang lingkup materi secara komprehensif. Hal ini dipertegas lagi menurut hasil penelitian $\mathrm{Wu}$, at-all (2001) mengatakan bahwa menggunakan peta konsep dapat meningkatkan kemampuan siswa dalam memahami mekanisme materi. Selanjutnya kriteria kesesuaian penugasan praktikum untuk mencapai tujuan pembelajaran, dan kesesuaian glosarium dengan materi semuanya sudah layak, hal ini disebabkan materi yang dikembangkan dalam Handout telah mengikuti perkembangan ilmu terkini yang membahas materi Kingdom Plantae. Berdasarkan kelima aspek diatas yang telah dinilai oleh validator, hasil validasi ahli materi memperoleh nilai persentase sebesar $96 \%$ dengan kategori sangat layak dipergunakan.

Berdasarkan hasil validasi yang dilakukan oleh validator ahli praktisi yang telah dijabarkan pada tabel.Aspek dengan perolehan persentase tertinggi adalah aspek cakupan pendekatan kontekstual dengan kategori sangat layak. Aspek pendekatan kontekstual terbagi menjadi 2 kriteria dengan perolehan nilai persentase tertinggi sebesar $100 \%$ dengan kategori sangat layak. Hal ini menunjukkan bahwa Handout bermuatan pendidikan karakter berbasis kontekstual yang dikembangkan dari segi isi dan penugasan praktikum sudah berbasis kontekstual dan sesuai dengan materi. Kriteria pendekatan kontekstualnya yaitu, keterkaitan antara materi yang diajarkan dengan pengetahuan yang dimiliki oleh siswa serta kemampuan mendorong siswa membuat hubungan antara pengetahuan yang dimiliki siswa dengan penerapannya dalam kehidupan sehari-hari. Lase, (2016) menyatakan bahwa penggunaan potensi lokal dalam pembelajaran melatih kemampuan siswa untuk bersosialisasi dan keterampilan memecahkan masalah potensi lokal yang ada di lingkungannya. Pembelajaran seperti ini di harapakan dapat memotivasi siswa untuk lebih semangat lagi dalam belajar dan memahami materi.

Aspek dengan penilaian terendah oleh ahli praktisi yaitu aspek desain dan aspek muatan pendidikan karakter yang perolehan nilai persentasenya sebesar $90 \%$ dengan kategori sangat layak. Salah satu aspeknya adalah aspek desain yang terdiri dari 2 kriteria yang nilai persentasenya sebesar 90\% dengan kategori sangat layak. Handout yang dikembangkan menggunakan desain yang menarik sehingga dapat menimbulkan minat baca pada siswa. Desain cover pada Handout yang dikembangkan sangat sederhana dan menarik serta mewakili isi materi yang terdapat pada Handout sehingga siswa mendapatkan gambaran secara umum mengenai apa yang akan dibahas didalam Handout tersebut dan dapat menarik minat siswa untuk membacanya. Hal ini sesuai dengan pernyataan Wibawa (2014) yang menyatakan bahwa sampul (cover) buku memberikan gambaran dari isi buku sehingga dapat menumbuhkan minat siswa untuk membaca buku pelajaran yang bersangkutan. Kemanarikan desain isi Handout juga dimata materi yang ditata rapi sesuai layoutnya serta penambahan nilai karakter dalam halaman materi yang menambah penjelesan serta penanaman nilai karakter dalam diri siswa.

Berdasarkan hasil validasi kelayakan dari ahli media, ahli materi, dan ahli praktisi, persentase skor dari ketiga validator dapat dilihat pada tabel 4.13 hasil penilaian dari ahli media diperoleh nilai persentase sebesar 89,4\% dengan kategori sangat layak, dari ahli materi dengan persentase sebesar $96 \%$ dengan kategori sangat layak, dan ahli praktisi persentase sebesar 94,\% dengan kategori sangat layak. Dari ketiga skor tersebut diperoleh nilai rata-rata sebesar 93\% dengan kategori sangat layak. Riduwan (2013) menyatakan bahwa tingkat 


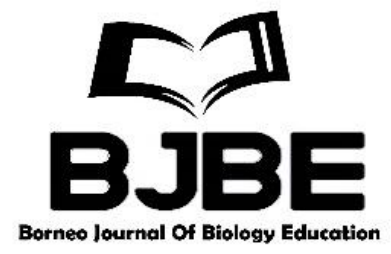

Vol. 3 No. 1, 2021; pp. 29-41

P-ISSN: 2715-6826 (print); E-ISSN: 2714-6073 (online)

Received: $16 / 02 / 2021$

Revised: 03/03/2021

Accepted: 18/03/2021

kategori kelayakan berada pada rentang $81 \%$ - $100 \%$ dan termasuk dalam kategori sangat layak, dengan demikian Handout pembelajaran biologi bermuatan pendidikan karakter berbasis kontekstual pada materi Kingdom Plantae di kelas X SMAK Frater Don Bosco Tarakan dinyatakan sangat layak untuk digunakan sebagai bahan ajar biologi.

\section{Hasil Uji Kepraktisan}

Handout bermuatan pendidikan karakter berbasis kontekstual pada materi kingdom plantae di kelas X SMAK Frater Don Bosco Tarakan yang dikembangkan telah di uji cobakan melalui uji respon siswa yang dilakukan secara online, dengan membagikan bahan ajar dalam bentuk file serta link google form yang berisi lembar angket siswa. Angket yang dibuat secara online diisi oleh 30 dari subjek uji coba. Uji respon siswa yang dilakukan pada tanggal, 12 Oktober 2020.

Berdasarkan hasil analisis skor validasi keseluruhan oleh validator, maka didapatkan nilai persentase kualitas kelayakan keseluruhan sebesar 93\% dengan kriteria sangat layak, dengan demikian dapat disimpulkan bahwa Handout bermuatan pendidikan karakter berbasis kontekstual pada materi kingdom plantae di Kelas X SMAK Frater Don Bosco Tarakan, layak digunakan oleh siswa.

Tabel 6. Hasil Angket Respon Siswa

\begin{tabular}{ccccccc}
\hline No & Aspek Penilaian & $\begin{array}{c}\sum \text { Skor } \\
\text { Maksimal }\end{array}$ & $\begin{array}{c}\text { S Skor } \\
\text { diperoleh }\end{array}$ & $\begin{array}{c}\text { Persentase } \\
(\%)\end{array}$ & $\begin{array}{c}\text { Persentase } \\
(\%) \text { Diagram }\end{array}$ & Kategori \\
\hline 1. & Aspek Tampilan & 150 & 130 & $87 \%$ & $25 \%$ & Sangat Layak \\
Handout & & & & & & \\
2. & Aspek & 150 & 128,5 & $86 \%$ & $25 \%$ & Sangat Layak \\
& $\begin{array}{c}\text { Pemahaman } \\
\text { 3. Aspek Penyajian }\end{array}$ & 150 & 129 & $86 \%$ & $25 \%$ & Sangat Layak \\
4. Aspek Bahasa & 150 & 134 & $89 \%$ & $25 \%$ & Sangat Layak \\
$\quad$ JUMLAH & 150 & 130 & $87 \%$ & $100 \%$ & Sangat Layak \\
Deskripsi Persentase & & & & & \\
$\quad(\%)$ & & & & & \\
\hline
\end{tabular}

Hasil uji coba Handout bermuatan pendidikan karakter berbasis kontekstual pada materi Kingdom Plantae di kelas X SMAK Frater Don Bosco Tarakan mendapat skor 130 dengan persentase $87 \%$ dengan kriteria sangat layak. Selain mendapatkan penilaian berupa data kuantitatif siswa juga memberi respon penilaian dengan data kualitatif yaitu berupa komentar dan saran terhadap Handout yang dikembangkan. Berdasarkan kriteria interpretasi penilaian respon siswa yang menyatakan bahwa Handout bermuatan pendidikan karakter berbasis kontekstual yang dikembangkan dikatakan sangat praktis apabila semua aspek dalam angket respon siswa memperoleh presentase sebesar (81\%-100\%) dengan kriteria sangat praktis. 

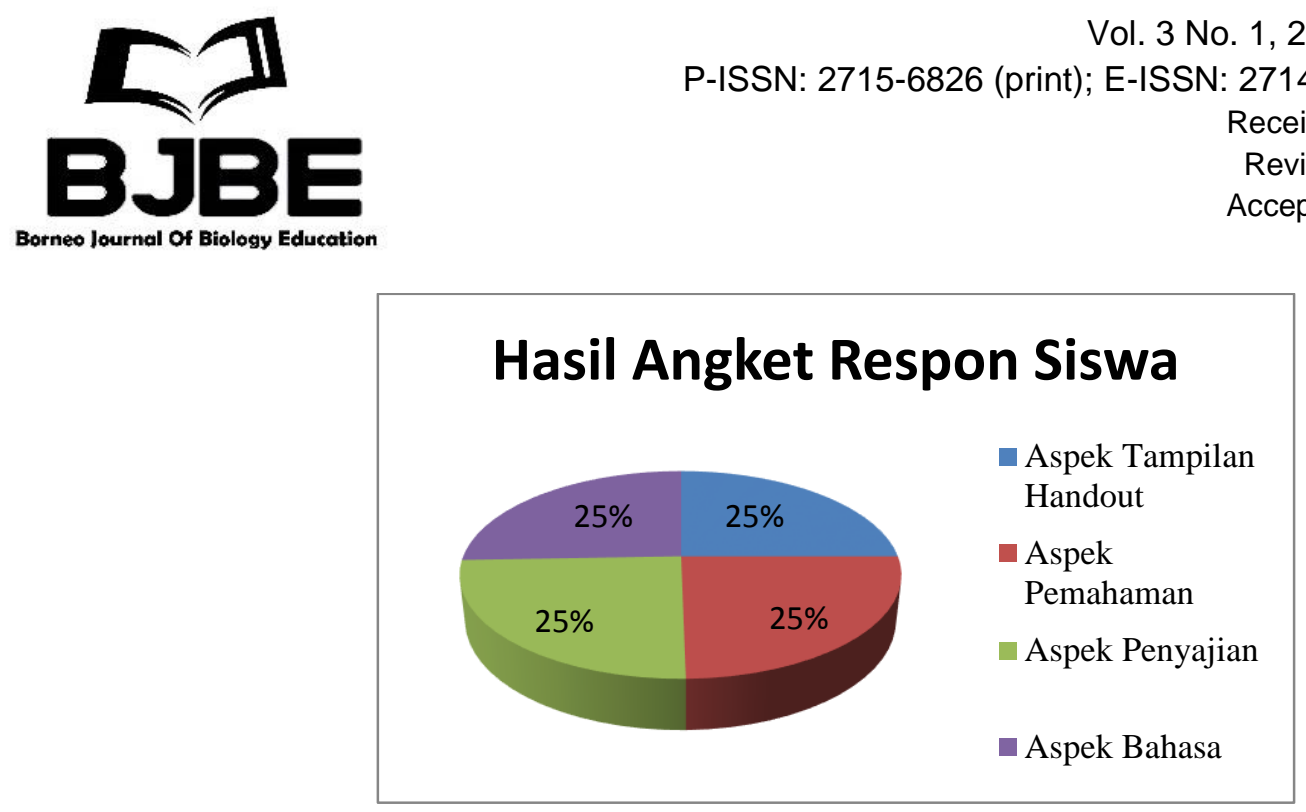

Gambar. Diagram Hasil Angket Respon Siswa

Pada diagram lingkaran terlihat jelas pembagian perolehan persentase ahli praktisi dalam hitungan rata-rata setiap aspek sehingga jumlah keseluruhan persentase menjadi $100 \%$. Dimana beberapa aspek yang dinilai oleh siswa memiliki persentase yang hampir sama pada diagram lingkaran yang telah dibuat. Mulai dari aspek tampilan Handout, aspek pemahaman, aspek penyajian dan aspek bahasa semuanya memperoleh persentase sebesar $25 \%$ setelah dilakukan uji coba produk terhadap siswa.

Uji coba produk dilakukan secara online pada 30 siswa kelas XI IPA di SMAK Frater Don Bosco Tarakan yang telah mempelajari materi Kingdom Plantae sebelumnya. Tujuan uji coba produk ini untuk mengetahui bagaimana respon siswa terhadap Handout bermuatan pendidikan karakter berbasis kontekstual yang telah dikembangkan. Berdasarkan 16 point kriteria pernyataan yang terdapat dalam lembar angket respon siswa pada tabel. Aspek penilaian yang diukur dalam uji coba produk kepada siswa yaitu aspek tampilan Handout, aspek pemahaman, penyajian, dan aspek bahasa. Aspek dengan perolehan persentase peniilaian yang tertinggi pada saat uji coba produk kepada siswa adalah aspek bahasa yang perolehan persentasenya sebesar $89 \%$ dengan kategori sangat layak.

Aspek bahasa terdiri dari satu komponen saja yaitu bahasa dalam Handout mudah dipahami oleh siswa sesuai dengan pernyataan Sadjati (2015) mengatakan bahwa bahasa menjadi salah satu faktor yang penting dan sangat berpengaruh terhadap Handout, walaupun isi Handout sudah baik dan dikemas menarik, namun jika bahasa yang digunakan tidak dimengerti maka Handout tidak bermakna apa-apa. Dipertegas lagi dengan pernyataan Prastowo (2012) yang menyatakan bahwa bahasa atau kalimat yang disajikan dalam Handout tidak boleh terlalu panjang dan harus disesuaikan dengan tingkat perkembangan peserta didik, intinya sederhana, singkat, jelas dan efektif dengan demikian peserta didik akan mudah memahaminya.

Salah satu aspek yang terendah yaitu, aspek penyajian dengan persentase sebesar $86 \%$ juga dengan kriteria sangat layak dimana terdiri dari 5 komponen pernyataan yaitu Handout dapat memberikan motivasi (ketertarikan) pada siswa untuk belajar, hal ini sesuai dengan penyataan Khoirowati (2012) mengatakan buku ajar yang dikembangkan hendaknya dapat memberikan manfaat, meransang, dan menunjukkan aktivitas siswa, serta memotivasi siswa dalam pembelajaran. Selanjutnya penyajian materi sangat lengkap, siswa mendapat pengetahuan yang lebih mudah dipahami tentang materi yang sekaligus dikaitkan dengan 


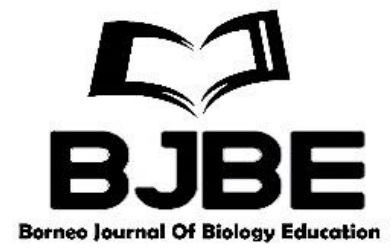

Vol. 3 No. 1, 2021; pp. 29-41

P-ISSN: 2715-6826 (print); E-ISSN: 2714-6073 (online)

Received: 16/02/2021

Revised: 03/03/2021

Accepted: 18/03/2021

nilai-nilai pendidikan karakter serta gambar yang disajikan sesuai dan mendukung kejelasan materi dengan berbagai jenis gambar yang sebagian besar diambil dari lingkungan sekitar siswa ynag diharapkan dapat membantu pemahaman siswa tentang materi, kejelasan keterangan dan sumber gambar dalam Handout.

Sesuai dengan pernyataan Komalasari, (2017) yang menyatakan bahwa suatu gambar atau foto dapat memberikan gambaran gambaran nyata yang menunjukkan objek sesungguhnya, memberikan makna pembelajaran yang lebih hidup dan tepat dibandingkan dengan kata-kata sehingga meransang kemampuan berfikir siswa. Dengan demikian sumber belajar akan berpengaruh positif terhadap kegiatan pembelajaran terutama pada peningkatan motivasi belajar siswa. Berdasarkan hasil respon siswa dapat disimpulkan persentase skor penilaian siswa diperoleh nilai rata-rata skor 130 dan persentase sebesar $87 \%$ dengan kategori sangat layak atau sangat menarik. Riduwan (2013) menyatakan tingkat kategori kemenarikan berada pada rentang 81\% - 100\% termasuk dalam kategori sangat menarik, dengan demikian Handout bermuatan pendidikan karakter berbasis kontekstual pada materi Kingdom Plantae di kelas X SMAK Frater Don Bosco Tarakan dinyatakan sangat menarik untuk digunakan dalam proses pembelajaran biologi disekolah.

\section{Kesimpulan}

Berdasarkan hasil penelitian dan pembahasan, dapat disimpulkan bahwa: Penelitian ini menghasilkan produk berupa Handout bermuatan pendidikan karakter berbasis kontekstual pada materi kingdom plantae yang dikembangkan dengan menggunakan model 4D dari Thiagarajan dimana terdiri dari 4 tahap pengembangan yaitu tahap define, design, development, dan disseminate tetapi pada pengembangan ini dibatasi sampai pada tahap ke 3 yaitu development. Kelayakan Handout pembelajaran bermuatan pendidikan karakter berbasis kontekstual pada materi kingdom plantae di kelas X SMAK Frater Don Bosco Tarakan yang dikembangkan telah dinilai oleh 3 ahli/pakar yakni, ahli media, ahli materi dan praktisi. Berdasarkan ketiga skor penilaian dari para ahli diperoleh nilai persentase dengan rata-rata sebesar 93\% dengan kategori sangat layak serta telah diuji cobakan kepada siswa kelas X SMAK Frater Don Bosco Tarakan yang dikembangkan dengan memperoleh hasil angket respon siswa sebesar $87 \%$ (sangat menarik).

\section{Ucapan Terima Kasih}

Kami mengucapkan terimakasih kepada Ketua Jurusan Pendidikan Biologi Fakultas Keguruan dan Ilmu Pendidikan Universitas Borneo Tarakan, berserta civitas akademik yang membantu kelancaran penelitian dan tak lupa kepada Kepala Sekolah SMAK Frater Don Bosco Tarakan yang telah mengizinkan dan membantu penelitian sampai selesai.

\section{Daftar Pustaka}

Anifah, R., Kasrina., \& Ansori, A. (2018). Pengembangan Handout Biologi Materi Keanekaragaman Hayati Untuk SMA Kelas X. Diklabio: Jurnal Pendidikan dan Pembelajaran Biologi, 2(2): 44-51 (2018). 


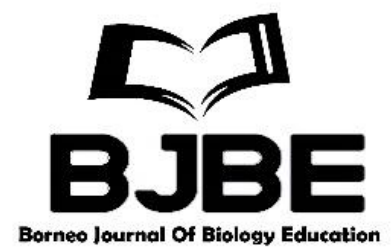

Vol. 3 No. 1, 2021; pp. 29-41

P-ISSN: 2715-6826 (print); E-ISSN: 2714-6073 (online)

Received: 16/02/2021

Revised: 03/03/2021

Accepted: 18/03/2021

Anggela, M. (2013). Pengembangan Buku Ajar Bermuatan Nilai-nilai Karakter Pada Materi Usaha dan Momentum untuk Pembelajaran Fisika Siswa Kelas XI SMA. Pillar of Physics Education, 1(1).

Arsanti, M. (2018). Pengembangan bahan ajar mata kuliah penulisan kreatif bermuatan nilainilai pendidikan karakter religius bagi mahasiswa prodi PBSI, FKIP, UNISSULA. KREDO: Jurnal Ilmiah Bahasa dan Sastra, 1(2), 69-88.

Asriani, Pity, (2017). Pendidikan Karakter Dalam Kegiatan Pembelajaran. Jurnal Ilmu Pendidikan.(http://pasca.um.ac.id/conferences/index.php/gtk/article/viewFile/314/297

Depdiknas. (2008). Panduan Pengembangan Bahan Ajar. Jakarta: Direktorat Jenderal Manajemen Pendidikan Dasar dan Menengah.

Fitri, A. Z. (2012). Pendidikan Karakter Berbasis Nilai dan Etika di Sekolah. Yogyakarta: Ar-Ruzz Media.

Lickona, T. (2006). Educating For Character. Jakarta. Bumi Aksara

Mulyoto. (2013). Strategi Pembelajaran di Era Kurikulum 2013. Jakarta: Prestasi Pustrakaraya.

Mustofa, A., \& Cintamulya, I. (2017). Pengembangan Handout Materi Biologi SMP Berbasis Pendekatan Konsep pada Sistem dalam Kehidupan Manusia. In Proceeding Biology Education Conference: Biology, Science, Enviromental, and Learning (Vol. 14, No. 1, pp. 591-597).

Prasetyo, A. \& Rivansintha, E. (2011). Konsep Urgensi dan Implementasi Pendidikan Karakter di Sekolah. Http://edukasi.kompasiana.com/2011/05/27/konsep-urgensi-danimplementasi-pendidikan-karakter-disekolah/

Prastowo, A. (2013). Panduan Kreatif Membuat Bahan Ajar Inovatif: Menciptakan Metode Pembelajaran yang Menarik dan Menyenangkan. Yogyakarta: Diva Press.

Putri, E. P. (2017). Pengembangan Bahan Ajar Biologi Berbasis Contextual Teaching and Learning (CTL) pada Pokok Bahasan Materi Sistem Gerak untuk Siswa Kelas VIII MTs As' adiyah Pongka Kec. Tellu Siattinge Kab. Bone (Doctoral dissertation, Universitas Islam Negeri Alauddin Makassar).

Rafiqah. (2013). Pengembangan Perangkat Pembelajaran Berbasis Konstruktivisme Cet. I. Makassar: Alauddin University Press.

Riduwan. (2014). Skala Pengukuran Variabel-variebel Penelitian. Bandung: Alfabeta

Riduwan. (2013). Skala Pengukuran Variabel - variabel Penelitian. Bandung: Alfabeta. 


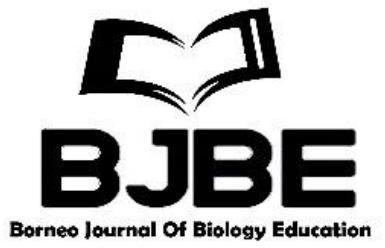

Vol. 3 No. 1, 2021; pp. 29-41

P-ISSN: 2715-6826 (print); E-ISSN: 2714-6073 (online)

Received: 16/02/2021

Revised: 03/03/2021

Accepted: 18/03/2021

Hera, R., Khairil, K., \& Hasanuddin, H. (2014). Pengembangan Handout Pembelajaran Embriologi Berbasis Kontekstual Pada Perkuliahan Perkembangan Hewan Untuk Meningkatkan Pemahaman Konsep Mahasiswa di Universitas Muhammadiyah Banda Aceh. Jurnal EduBio Tropika, 2(2).

Sugiyono. (2015). Metode Penelitian Kombinasi (Mix Methods). Bandung: Alfabet.

Thiagarajan, S. (1974). Instructional Development for Training Teachers of Exceptional Children: A Socurcebook. Minnesota: Center for Innovation Teaching the Aandycapped Indiana University.

Wibawa, M. (2014). Analisis Kualitas Desain Sampul Buku Sekolah Elektronik (BSE) Mata Pelajaran Seni Budaya. Artikel Publikasi. Universitas Negeri Surabaya.

Widadi, M. (2012). Pengembangan Handout Pembelajaran Kerja Bangku di SMK NEGERI 1 SEYEGAN. Skripsi. Pendidikan Teknik Mesin Fakultas Teknik Universitas Negeri Yogyakarta : Yogjakarta

Wulandari, Y., \& Purwanto, W. E. (2017). Kelayakan aspek materi dan media dalam pengembangan buku ajar sastra lama. Jurnal Penelitian Pendidikan Bahasa dan Sastra Indonesia, 3, 162-172. 